\title{
¡Dios salve a la razón y... a la religión! de J. Ratzinger a Benedicto XVI
}

\author{
Discurso de Ratisbona
}

\author{
Domingo Natal Álvarez
}

SUMARIO: La fe y razón se unen en la construcción del hombre y el mundo. Aquí se trata de ver la relación entre fe y razón, tanto en la historia del cristianismo como en relación con las otras religiones. Y, finalmente, en la historia de nuestro mundo, sin dejar de lado el problema de la religión y la violencia, ni las diversas patologías de las que pueden y deben curarse mutuamente tanto la razón como la religión hoy.

ABSTRACT: The faith and the reason are going together in the construction of the man and the world. Here, we are seen the relation between the faith and the reason in the history of Christian people and with the other religions. Ending, we see the history of our world, without lay out of way the problem of religion and violence, and we put on the mirror the pathologies of religion and reason and his mutual correction.

\section{Cristianismo y cultura. Fe y razón}

El Papa, Benedicto XVI, nos asegura que el cristianismo es una religión que ha simpatizado con el Logos griego y la razón humana, incluso con la feliz traducción griega del Antiguo Testamento, dando mucho valor a la razón. De ahí que "no actuar según la razón, el Logos, es ir contra la naturaleza de Dios". 
No obstante, ha habido una 1 ${ }^{\mathrm{a}}$.- Des-helenización del cristianismo con el luteranismo. Una $2^{\mathrm{a}}$.- Des-helenización con Harnack y la escuela histórica al olvidar lo que no es de mera razón como la divinidad de Jesucristo, el misterio de la Trinidad, etc. Y, una como 3 a .- Des-helenización que funde el cristianismo en otras culturas.

Ahora bien, no se trata de dejar la Ilustración y la modernidad sino de buscar una razón abierta, superando el instrumentalismo, con un sentido trascendente de la vida y en diálogo con las otras religiones y culturas. Por otra parte, la religión y la razón sufren patologías. La razón libra a la religión de patologías como la superstición, maniqueísmo, magias y astrología. Y, la religión libra a la razón de escepticismos, relativismos, fetichismos, fundamentalismos y monolitismos y otros engaños. Además, según G. Bueno, no se puede decir que la Iglesia se opone a la ciencia, pues tiene a Copérnico, Lemaître, Saccheri, Mendel, y otros padres de la ciencia actual.

Para A. Glucksmann, Benedicto XVI ha puesto a las religiones ante sí mismas y ante el gran tema del siglo XXI: el problema de la violencia. Pues, las religiones, con sus propios caminos y modos de entender la vida, buscan el bien de sus gentes en el "Dios bendito" del AT., en la Eucaristía del NT y en Allah siempre más grande y misericordioso. Además, la religión crea en Occidente la Universidad que busca la verdad y ama la razón humana. Y, creó el derecho de gentes y los derechos humanos fundamentales. El cristianismo se preocupó siempre del hombre, de la educación de las personas en libertad y del progreso de los pueblos desde una fe confiada en Dios y el amor al prójimo.

Para J. Prades: "El modelo teórico del mundo moderno no consigue pensar unidos el saber y la libertad", considerado "el distintivo de la época"1. La razón liberada de las tutelas externas tradicionales: "Podía pues ofrecer un saber universal tanto en el campo de las ciencias naturales y sociales como en el de la ética e incluso en el de la religión dentro de los límites de la razón": R 9. Pero, de hecho, muchos pensadores "del siglo $\mathrm{XX}$ han arrancado a la razón moderna de los atributos que casi la convertían en divina": "dar razón sólo a partir de sí misma”: R 10. Por eso:

${ }^{1}$ Benedicto XVI- G. Bueno, A. Glucksmann y otros, Dios salve la Razón. Presentación J. Prades (7- 27). Eds. Encuentro, Madrid 2008, 9. En adelante R. 
"Al decir que la razón se ha perdido, se alude al hecho de que la posmodernidad ha acuñado un concepto tan débil de razón que la despoja de los atributos que un día la convirtieron en símbolo del mundo moderno": $\mathrm{R}$ 8. Pero, otros creen que una razón más humilde como la posmoderna podría ofrecer una visión más auténtica de la realidad, puesto que: "La mera contingencia experimental no puede fundamentar la razón. Este es, a mi juicio, el diagnóstico decisivo: la razón posmoderna se concibe de tal manera que no puede dar razón de su sentido ni de sí misma desde la premisa que ella misma establece": R 11.

Por otra parte: "No es tampoco extraño que muchas manifestaciones de la libertad sean meras reacciones de violencia ante un orden de la razón instrumental que no es capaz de contemplar las exigencias y preguntas humanas". Y, como dice H. Arendt: "El objeto ideal de la dominación totalitaria no es el nazi convencido o el comunista convencido, sino las personas para quienes ya no existen la distinción entre el hecho y la ficción, y la distinción entre lo verdadero y lo falso": R 12. Pues, si "el esfuerzo ímprobo de la razón", para salvar su "sentido y utilidad, ha fracasado", o nos resignamos a "la opresión económica y política de la razón instrumental”, con sus sombrías consecuencias, "o es necesario 'salvar la razón"”: R 13.

Es cierto, que para Lessing y su "razón adulta" como para Hegel: "Lo cristiano en la historia sería como un auxiliar de la evolución de la filosofía. Para Kant la revelación cristiana, exterior, agota su misión cuando llega la auto-fundamentación de la razón". Así: "El cristianismo se resuelve en religión, y la religión en filosofía" igual que: "Los padres y educadores ejercen una autoridad muy valiosa, pero provisional, ya que representan una autoridad que luego surgirá de la razón misma cuando se desarrolle autónomamente": R 15-6. Ahora bien: la razón pura, encerrada en sí misma, confiesa "su impotencia para conocer la verdad: sería la incapacidad confesa del discurso racional para ser ontológico": R 18.

Para Agustín de Hipona el impulso del hombre a filosofar es buscar "su felicidad", y santo Tomás afirma que "la verdad primera coincide con el fin de los deseos y acciones humanas": R 19. Así que, "solo por un testimonio del Absoluto, la razón puede alcanzar de un modo pleno aquello que busca": "Dios creador, infinitamente libre, es la respuesta metafísica a la razón del hombre que busca su fundamento": R 20-1. Pues: "El Logos de Dios se ha hecho carne y habita entre nosotros (Jn 1,14)". Podemos 
conocer y amar a Aquel que es "el fundamento de nuestra razón, fuente y fin último de nuestro deseo de felicidad". Así, en "la historia de la salvación (creación y encarnación redentora)", todos somos convocados "a dar testimonio del Dios vivo y verdadero": R 22-23.

Los discursos de Benedicto XVI, como el de Ratisbona, bien valorados por los que "aman la razón", enseñan que: Solo un hombre "razonable y libre, puede obtener de sus interlocutores un respuesta igualmente razonable y libre". Lo mismo se debe decir de su "disposición para contrastar su pensamiento con representantes agnósticos del mundo laico como Pera, Habermas o Flores D'Arcais". "Siguiendo sus huellas se podrán encontrar en el mundo pos-moderno interlocutores en la tarea de dignificar la razón". Esta edición añade a Juaristi y G. Bueno. Este reivindica el "papel del Dios del catolicismo en defensa de la razón, frente a desviaciones y patologías". Como dice Chesterton a un falso sacerdote: "usted atacó la razón y eso es de mala teología": R 24-27.

\section{Benedicto XVI: "Fe, Razón y Universidad. Recuerdos y reflexiones"}

En la Universidad ha habido siempre una "común responsabilidad respecto al recto uso de la razón: era algo que se experimentaba vivamente": R 30. Además, "interrogándose sobre la racionalidad, se realiza un trabajo que forma parte necesariamente del conjunto de la "Universitas scientiarum", aunque no todos tenían "la fe, a cuya correlación con la razón común se dedican los teólogos”: R 30.

Pues bien, "en cierta ocasión, se supo que uno de los profesores había dicho que en nuestra universidad había algo extraño: dos facultades que se ocupaban de algo que no existía: Dios”. Pero, para el conjunto de la Universidad, "seguía siendo necesario y razonable interrogarse sobre Dios por medio de la razón y que esto debía hacerse en el contexto de la tradición de la fe cristiana": R 30.

Ratzinger recuerda todo esto, al leer la obra del profesor Th. Khoury que cita el diálogo del emperador bizantino, Manuel II Paleólogo, con un persa culto sobre el cristianismo y el islam. Hablan sobre la Biblia y el Corán. Aunque el emperador seguramente sabía que la sura 2.256 dice: "Ninguna constricción en las cosas de fe": R 31. Con todo, con una 
"brusquedad que para nosotros resulta inaceptable, se dirige a su interlocutor llanamente con la pregunta central sobre la relación entre religión y violencia en general diciendo: Muéstrame también lo que Mahoma ha traído de nuevo, y encontrarás solamente cosas malas e inhumanas, como su disposición a difundir por medio de la espada la fe que predicaba" (Controversia VII 2c: Khoury, pp. 142-143): R 31-32.

El emperador explica las razones de su dureza: "Dios no se complace con la sangre -dice-; no actuar según la razón (sùnlógoo) es contrario a la naturaleza de Dios. La fe es fruto del alma, no del cuerpo. Por tanto, quien quiere llevar a otra persona a la fe necesita la capacidad de hablar bien y de razonar correctamente, y no recurrir a la violencia ni a las amenazas" (Controversia VII, 3 b-c: Khoury, pp.144-145): R 32 y n.5.

Ahora bien: "En esta argumentación contra la conversión mediante la violencia, la afirmación decisiva es: no actuar según la razón es contrario a la naturaleza de Dios" ("n.6: Solamente por esta afirmación cité el diálogo entre Manuel II y su interlocutor persa. Ella nos ofrece el tema de mis reflexiones sucesivas": R 32 (cursiva mía). El mismo Khoury comenta que para el emperador bizantino esto es evidente, pero para la doctrina musulmana Dios es transcendente y no tiene por qué sujetarse ni a su propia palabra como dice Ibn Hazm: R 32-33. Eso mismo piensan muchos teólogos medievales cristianos como Escoto: R 35. Pero el IV concilio de Letrán dice que Dios no es caprichoso y que hay cierta analogía entre Dios y el hombre y que, su distancia, no destruye esa "analogía y su lenguaje": R 35.

Así, según Ratzinger la comprensión de Dios nos plantea un desafío muy directo: "La convicción de que actuar contra la razón está en contradicción con la naturaleza de Dios, ¿es solamente un pensamiento griego o vale siempre y por sí mismo? Pienso que en este punto se manifiesta la profunda consonancia entre lo griego en su mejor sentido y lo que es fe en Dios según la Biblia. Modificando el primer versículo del libro del Génesis, el primer versículo de toda la sagrada Escritura, san Juan comienza el prólogo de su Evangelio con las palabras: En el principio ya existía el Logos'. Esta es exactamente la palabra que usa el emperador, Dios actúa sìnlógoo" (...) "En el principio existía el logos, y el logos es Dios, nos dice el evangelista. El encuentro entre el mensaje bíblico y el pensamiento griego no era una simple casualidad": R 33. 
Para Ratzinger en el "Yo soy" del A.T.: "con este nuevo conocimiento de Dios se da una especie de Ilustración, que se expresa drásticamente con la burla de las divinidades que no son sino obra de las manos del hombre (cf. Sal 115)": R 34. Según él, también la traducción del A.T., de los Setenta, es un hecho providencial en la historia de la revelación, pues ahí se realizó un encuentro decisivo en "el nacimiento y la difusión del cristianismo. En el fondo, se trata del encuentro entre fe y razón, entre auténtica ilustración y religión". Partiendo de la íntima naturaleza de la fe cristiana y del pensamiento griego fusionado con la fe, "Manuel II podía decir: no actuar con el logos es contrario a la naturaleza de Dios": R 34-5.

Es más, Dios no es más Dios por ser lejano y desconocido del hombre sino que el Dios verdadero y divino "es el Dios que se ha manifestado como logos y ha actuado y actúa como logos lleno de amor por nosotros". Y, es "el amor de Dios-Logos, por el que el culto cristiano, como nos dice san Pablo, es logikélatreia, un culto que concuerda con el Verbo eterno y con nuestra razón (cf. Rm 12,1)": R 36, y cf. n.11. No obstante, ha habido 3 momentos de des-helenización del cristianismo:

$I^{\circ}$.- En el s. XVI, el Protestantismo trata de purificar la fe de una filosofía contraria a la Biblia. Kant radicalizó este proceso y "ancló la fe exclusivamente en la razón práctica, negándole el acceso a la realidad plena": R 37.

$\mathrm{II}^{\mathrm{o}}$.- "La idea central de Harnack era simplemente volver al hombre Jesús y a su mero mensaje, previo a todas las elucubraciones de la teología" y sus helenizaciones. Este mensaje constituiría "la verdadera culminación del desarrollo religioso de la humanidad", y Cristo es el "padre de un mensaje moral humanitario". Así, Harnack pretendía poner el cristianismo de acuerdo con la mentalidad moderna, librándolo de elementos teológicos y filosóficos como "la fe en la divinidad de Cristo", etc.: R 38. Así, la teología se convertía también en "algo esencialmente histórico, y, por tanto, estrictamente científico" (...) "presente también en el conjunto de la universidad", y supone la limitación moderna de la razón de "las críticas de Kant, aunque radicalizada ulteriormente entre tanto por el pensamiento de las ciencias naturales": R 38.

Entonces, solo "la experimentación ofrece la certeza decisiva. El peso entre los dos polos (matemático-platónico y experimental)" de- 
pende de las circunstancias. Un pensador drásticamente positivista, como J. Monod, declaró: "Solo el tipo de certeza que deriva de la sinergia entre matemática y método empírico puede considerarse científica". Y: "este método en cuanto tal excluye el problema de Dios, presentándolo como un problema a-científico o pre-científico". Así, estamos "ante una reducción del ámbito de la ciencia y de la razón que es preciso poner en discusión": R 39.

Porque, así: "El sujeto, basándose en su experiencia, decide lo que considera admisible en el ámbito religioso, y la conciencia subjetiva se convierte, en definitiva, en la única instancia ética. Pero, de este modo, el ethos y la religión pierden su poder de crear una comunidad y se convierten en un asunto totalmente personal. La situación que se crea es peligrosa para la humanidad, como se puede constatar en las patologías que amenazan a la religión y a la razón". Estas irrumpen por necesidad cuando a la razón "no le interesan las cuestiones de la religión y de la ética": R 39-40. Así, la psicología y la sociología querrán pasar por religión y ética.

III $^{\circ}$.- Esta etapa de la des-helenización plantea que la actual situación intercultural exige una nueva aculturación del cristianismo. "Esta tesis no es del todo falsa, pero sí rudimentaria e imprecisa". Pues, en la formación de la Iglesia no todos sus elementos "deben integrarse en todas las culturas. Sin embargo, las opciones fundamentales que atañen precisamente a la relación entre la fe y la búsqueda de la razón humana forman parte de la fe misma, y son un desarrollo acorde con su propia naturaleza": $\mathrm{R}$ 40.

Conclusiones: $1^{\mathrm{a}}$.- La crítica de la razón moderna no rechaza la Ilustración. Se reconoce el valor del desarrollo moderno: todos estamos agradecidos por posibilidades que ha abierto al progreso de la humanidad. "Por lo demás, la ética de la investigación científica -como ha aludido usted, Señor Rector Magnífico-, debe implicar una voluntad de obediencia a la verdad y, por tanto, expresar una actitud que forma parte de los rasgos esenciales del espíritu cristiano": R 40-41.

$2^{\mathrm{a}}$.- Pero, se trata de evitar los peligros de una razón mutilada, por la sola experimentación. "En este sentido, la teología no solo como disciplina histórica y ciencia humana, sino como teología auténtica”, y ciencia que da razón de la fe, debe tener "espacio en la universidad y en el amplio diálogo de las ciencias": R 41. 
3a.- Hoy necesitamos del diálogo con las otras culturas y religiones. Occidente cree que el positivismo y sus filosofías son universales. Pero las culturas más religiosas del mundo consideran que esta exclusión de lo divino constituye "un ataque a sus convicciones más íntimas. Una razón que sea sorda a lo divino y relegue la religión al ámbito de las subculturas, es incapaz de entrar en el diálogo de las culturas". Con todo, la razón moderna de las ciencias naturales, con su elemento platónico intrínseco, pone un interrogante más allá de sí misma que trasciende su método. "La razón científica moderna ha de aceptar simplemente la estructura racional de la materia y la correspondencia entre nuestro espíritu y las estructuras racionales que actúan en la naturaleza como un dato de hecho, en el cual se basa". Y, debe reconocer "otros ámbitos más amplios y altos del pensamiento, como son la filosofía y la teología": R 41-42.

$4^{\mathrm{a}}$.- Ratzinger, cita a Sócrates en el Fedón: “ Sería fácilmente comprensible que alguien, a quien le molestaran todas estas opiniones erróneas, desdeñara durante el resto de su vida y se burlara de toda conversación sobre el ser; pero de esta forma renunciaría a la verdad de la existencia y sufriría una gran pérdida " (n.9: 90c-d): R 42. Occidente hace tiempo que sufre cierta aversión a los grandes temas y eso es una gran pérdida. Por eso, hay que abrirse a la grandeza de la razón que "es el programa con el que una teología comprometida con la reflexión sobre la fe bíblica entra en el debate de nuestro tiempo. No actuar según la razón, no actuar con el logos es contrario a la naturaleza de Dios, dijo Manuel II partiendo de su imagen cristiana de Dios, respondiendo a su interlocutor persa. En el diálogo de las culturas invitamos a nuestros interlocutores a este gran logos, a esta amplitud de la razón. Redescubrirla constantemente por nosotros mismos es la gran tarea de la universidad": R 42 .

Así, para Ratzinger, "El mundo tiene necesidad de Dios" como dice en la Homilía de la Misa en la Feria de Munich el 10.9.2006. Y muestra su alegría por visitar "los lugares en los que aprendí a creer y a vivir", y agradece "a todas las personas -vivas y muertas- que me han guiado y acompañado. Doy gracias a Dios por esta hermosa patria y por las personas que me la han hecho patria". Luego J.R. comenta las lecturas que: "Quieren guiarnos hacia Dios, llevándonos por el camino recto de la vida". El "tema de Dios va unido al tema social", a "nuestra responsabilidad para que reine la justicia y el amor en el mundo". "El amor al prójimo, que es en primer lugar preocupación por la justicia, es el metro para medir la fe 
y el amor a Dios. Santiago lo llama 'ley regia' (St 2,8)", y "'ley de la libertad'. Si todos pensamos y vivimos según Dios, entonces somos todos iguales, somos libres, y así nace la verdadera fraternidad": R 43-45.

"Jesús se dedica a los que sufren, a los marginados de la sociedad". Los cura y les da la posibilidad "de vivir y decidir juntamente con los demás, los introduce en la igualdad y en la fraternidad". Eso debemos hacer nosotros. "En nuestro bautismo él realizó sobre nosotros ese gesto de tocar y dijo: 'Effetá, 'Ábrete"”. Por la fe," Jesús quiere compartir con nosotros su ver a Dios, su escuchar al Padre y hablar con él": R 45-46. "La cuestión social y el Evangelio son realmente inseparables. Si damos a los hombres solo conocimientos, habilidades, capacidades técnicas e instrumentos les damos demasiado poco", pues, así, la técnica no "se pone al servicio del derecho y del amor": R 47-48. El utilitarismo y el cinismo de lo sagrado no es tolerancia verdadera pues hace falta un respeto que "solo puede renovarse en el mundo occidental si crece de nuevo la fe en Dios, si Dios está de nuevo presente para nosotros y en nosotros": Y, los hombres verán "la bondad de Dios, que vendrá a sanarlos". "Su 'venganza' es la cruz: el 'no' a la violencia, el 'amor hasta el extremo"”: R 48-9.

Así, para Ratzinger, La fe es sencilla, dice en la homilía, en el Islinger Feld de Ratisbona. La "fe nos reúne y nos regala una fiesta. Nos da la alegría en Dios, la alegría por la creación y por estar juntos”. “ ¡Gracias de todo corazón!'. Que el Señor os lo pague todo y que la alegría que ahora podemos experimentar gracias a vuestra preparación vuelva centuplicada a cada uno de vosotros". Habéis "colaborado para embellecer mi casa y mi jardín. Me emociona tanta bondad". "No habéis hecho todo esto por un hombre, por mi pobre persona; en definitiva, lo habéis hecho por la solidaridad de la fe, impulsados por el amor a Cristo y a la Iglesia. Todo esto es un signo de verdadera humanidad, que brota de haber sido tocados por Jesucristo": R 51-2. "Esta visión demuestra dos cosas: en primer lugar, que la fe es sencilla. Creemos en Dios, principio y fin de la vida humana". Y (que) la fe es amor, el amor que Dios “quiere 'contagiarnos'. Esto es lo primero: nosotros simplemente creemos en Dios, y esto lleva consigo también la esperanza y el amor": R 53. Se trata de un encuentro entre Dios y el hombre, pues en el bautismo, Dios se inclina hacia el hombre, sale a nuestro encuentro y "nos acerca unos a otros. Porque el bautismo significa que Jesucristo, por decirlo así, nos adopta como hermanos y hermanas suyos, acogiéndonos así como hijos en la familia de Dios": R 53. 
Pero: Desde la Ilustración, parte de la ciencia busca "una explicación del mundo en la que Dios sería superfluo. Y, si eso fuera así, Dios sería inútil también para nuestra vida": R 53. "Pues bien, creemos precisamente en el Dios que es Espíritu Creador, Razón creadora, del que proviene todo y del que provenimos también nosotros". "La segunda parte del Credo nos dice algo más. Esta Razón creadora es Bondad. Es Amor.Tiene rostro. Dios no nos deja andar a tientas en la oscuridad. Se ha manifestado como hombre. Es tan grande que se puede permitir hacerse muy pequeño. 'El que me ha visto a mí, ha visto al Padre', dice Jesús (Jn 14,9)”. Nos ama hasta morir por nosotros y llevar los sufrimientos humanos al "corazón de Dios": R 54. Esta es la humanidad de Dios que nos libra de toda injusticia. Además: "La fe no quiere infundirnos miedo; pero quiere llamarnos a la responsabilidad". (...) "por nuestra salvación y por la salvación de todo el mundo": R 55. Y, dado que Cristo nos dio a su Madre como madre nuestra: "Acojamos también nosotros a María como la estrella de nuestra vida, que nos introduce en la gran familia de Dios. Sí, el que cree nunca está solo. Amén": R 56.

\subsection{Gustabo Bueno: ¡Dios salve la razón!”}

"El mejor homenaje que, como expresión no meramente retórica de mi admiración, creo poder rendir a S.S. Benedicto XVI", "es el presente ensayo de 'traducir' esa re-lección a las coordenadas del materialismo filosófico que profeso": R 57. Esta colaboración, referida a la Vorlesung de Ratzinger, en Ratisbona, quiere mantenerse siempre "en la perspectiva definida por el título del libro que Edizioni Cantagalli utilizó para publicar, en 2007, la lección del Papa, en italiano", con comentarios de Glucksmann, Farouq, Nusseibeh, Spaemann y Weiler: "Dio salvi la Ragione": R 57.

En primer lugar, “los términos 'Razón' y 'Dios' no son términos unívocos" sino de "significados muy distintos" y, a veces, "incompatibles". Así, la Razón puede ser: razón lógico-formal, geométrica, calculadora, política, económica, emocional y “'razón de la sinrazón' de la que tanto gustaba Don Quijote”. Así, la idea de Razón es “una Idea compleja, opaca, oscura y confusa": R 58-59. Para el "formalismo lógico", la razón es una "estructura puramente formal", que conforma toda materia "de cualquier Mundo real": R 61. El formalismo psicológico cree en algo inmaterial que 
segregaría, "como ideas vacías, las Ideas de Alma, de Mundo o de Dios". "El racionalismo materialista sustancialista entiende la racionalidad "en el sentido del 'panlogismo materialista' según el cual 'todo lo real es racional' en el sentido de logos natural: la idea de suneijeia, 'coherencia', del estoicismo antiguo o medio": R 61. Así, el formalismo o sustancialismo "resultan de una hipóstasis de los componentes hile-mórficos de la realidad" (no al revés). Y, de ahí, 4 corolarios: $1^{\circ}$.- Del Dios de Aristóteles "no se puede predicar la racionalidad", pues no hace silogismos ni discursos (santo Tomás): R 62.

$2^{\circ}$.- "La concepción hile-mórfica de la racionalidad no incluye, desde luego, la violencia de sangre, pero tampoco la excluye": R 63. Eso parece decir Manuel II Paleólogo, que cita Ratzinger, "y que dio lugar a una reacción totalmente desproporcionada y desajustada en el mundo mahometano. 'Dios no se complace con la sangre; no obrar conforme a la razón, sunlogóo, es contrario a la naturaleza de Dios'”. Esta sentencia pacifista es defendible, pero no por la Razón atribuida al Dios de la Teodicea aristotélica. Y, no es que la Razón "incluya la violencia", sino que "no la excluye". Así, se da un empujón para evitar un atropello y usa violencia en legítima defensa: R 64.

30 "La Paz política o religiosa" no es la condición primera del "orden racional", sino resultado de un conflicto o guerra que conculca un orden previo y, así, una "de las partes en conflicto logra poner (no necesariamente restaurar) un orden nuevo, y por eso la Paz es siempre Paz de la Victoria", precaria, no "una Paz perpetua efectiva": R 65.

$4^{\circ}$. La conformación racional de un material "no agota ese material". La racionalidad de un discurso no siempre es "armónica (sinfónica)" con otros procesos sino que puede haber "diafonía": R 65. "El par de Ideas Materia/Forma mediante el cual hemos esbozado nuestro análisis de la racionalidad operatoria, está involucrado en el par de Ideas sintácticas Términos/ Relaciones": R 65. Desde este punto de vista, toda racionalidad es relacional, y, por eso, el Motor inmóvil de Aristóteles "no puede recibir tampoco por esta vía el predicado racional, porque el Dios de Aristóteles no puede hablar consigo mismo ni con el Mundo" que no ha creado y desconoce: R 67. Pero, el Logos se aplica al Verbo en el catolicismo, porque "en cuanto Dios habla a los hombres a través de Cristo". Pascal dice: "solo conozco a Dios a través de Jesucristo" (F. Suárez en De Trinitate, 9, 2): R 
67. El Universo tampoco es "racional", como omnitudo sustantiarum, pues él "no tiene entorno, y por ello no tiene contorno o bordes": R 69.

Aristóteles sería el fundador del monoteísmo, porque habla de un Dios Acto Puro, pero sin relación con los hombres, "al menos si entendemos la religión como una relación con el Dios del amor, con el Deus charitas est de san Juan ('el que no ama no ha conocido a Dios, porque Dios es amor' (I Carta, IV, 8)": R 70. Esta teología “veía a Dios como Verbo Divino, o Logos, a un Dios cuyas Personas podían ya 'hablar entre sí' y amarse, así como podían hablar y amar a los hombres": R 71. Por eso, no habría que unir tanto cristianismo, judaísmo e islamismo, como religiones del libro. Pues, aunque todas sean Religiones naturales (M. Müller), la alegoría de Nathan el sabio de Lessing, que las unifica, no gustó nada porque tenía "un principio demoledor de los contenidos más positivos de cada una de las religiones": R 73.

Muchos pueblos llegaron a la idea de Dios "por razonamientos muy similares a los que santo Tomás utilizó en las cinco vías: la Idea de un Dios único, omnisciente": R 74. Para Kant "la razón silogística", "nos lleva a poner a la Idea de Dios, en cuanto forma pura que se nos ofrecerá como 'Ideal de la Razón'”. Pero, según Pascal, “el Dios de los filósofos en realidad nada nos manifiesta a los hombres, porque 'es el corazón el que siente a Dios, y no la Razón' (Pensamiento 268), porque 'la fe es un don de Dios; no penséis que es un don del razonamiento (Pensamiento 269)": R 75. Luego, se impuso el Dios cartesiano: "Entendimiento infinito", del "Universo creado por él", y de la razón humana que "habría que considerar, al modo platónico, como un reflejo o participación del Entendimiento divino": $\mathrm{R} 76$.

Aún hoy, es difícil determinar lo que tiene que ver Dios con la razón cuando nos referimos a la "Teología voluntarista" de Escoto, Pascal o Unamuno, o cuando nos referimos a la "Teología intelectualista" que se resiste "a la equiparación del Entendimiento divino con la razón humana. Cabría decir que en el terreno de la Teología práctica, Duns Escoto se mantiene muy próximo a santo Tomás de Aquino": R 76-7. En todo caso: "Parece indudable que la misión salvífica del Dios cristiano" ha de "orientarse también a la salvación de la razón humana", porque esta también habría sido "afectada (según algunos teólogos, que siguen de cerca a san Agustín, quebrantada), y de muchas maneras, por el pecado original”: 
R 77. La "degeneración de la razón” es fácil de ver por psicólogos, pues, sus trastornos hacen "perder la razón": $\mathrm{R} 78$.

Hay trastornos de la razón, en relación a las religiones y de ciertas "épocas históricas", que corrigen algunas instituciones como esa "institución divina" que es "la Iglesia católica": R 79. Algunas instituciones políticas, científicas, económicas, militares, también sufren trastornos como una empresa en superproducción o por incapacidad de consumo de la población: R 80. Aquí, G. Bueno señala 4 casos:

“A) Desviaciones o trastornos de orientación supersticiosa”, incluida "la magia negra o a la magia blanca-'teurgia", "fetiches", "talismanes", “adivinaciones": R 80. "B) Desviaciones o trastornos (de orientación mitológica o ideológica delirante)”. “C) Desviaciones de orientación escéptica o nihilista": el relativismo, la trivialización o el "posmodernismo" que “determinan una 'crisis de confianza"”: R 81-2. “D) Registremos también, como desviaciones de la racionalidad, los dogmatismos o fundamentalismos institucionales, es decir, aquellas situaciones en las cuales determinadas corrientes de racionalidad", se declaran incompatibles con otras, "tendiendo por tanto a reducirlas, a neutralizarlas, o incluso a destruirlas". Así, el fundamentalismo islamista, se define "incompatible con las otras 'religiones de libro' y declara la Yihad contra ellas": R 82. Entonces el Dios del cristianismo puede salvar a la Razón de estas 4 desviaciones:

A) La salva de supersticiones como los cultos de Atis, Cibeles o el mitraísmo y los racionaliza "mediante la apelación constante a un Dios omnisciente, omnipotente y bondadoso, capaz de hablar a los hombres corrientes, como pescadores o artesanos": R 83-4. Así, el cristianismo salvó a la razón de la "hemorragia supersticiosa", de los perversos genios malignos que aterrorizan a los hombres. El Dios cristiano es una garantía de "sobriedad y de seguridad entonces inexpugnable": R 84. Eso hizo el Dios cristiano con los dioses aztecas y mayas de América aunque algunos lo critiquen: R 85.

B) El Dios cristiano de Ireneo, Hipólito y Agustín y Tomás de Aquino, salva a la razón de los extravíos del "delirio gnóstico" (Valentín o Marción) que crean unas cosmogonías y teogonías que son "ejemplos eminentes de racionalismo" "patológico", por no decir, de "una fantasía paranoica mito-poiéticamente desbordada": R 85. 
De hecho, la contribución científica de la Iglesia “deja en ridículo a la visión que, desde la Ilustración principalmente, pero sobre todo a lo largo del siglo XIX, como Draper" que pretendió presentar al catolicismo, como una corriente reaccionaria frente al Renacimiento, que había llamado "reanudar el racionalismo antiguo", con los famosos 'casos' de G. Bruno y Galileo: R 86. Porque, según G. Bueno: Ninguna otra religión puede presentar tantas "figuras de primera línea que fueron decisivas en las revoluciones de la ciencia moderna y actual" (...). "No puede olvidarse que la Revolución copernicana, con la que se abre habitualmente la ciencia astronómica moderna, fue obra de un clérigo católico, el que le dio nombre, Nicolás Copérnico": $R$ 87. "Y después de Copérnico, ¿cómo dejar de lado la figura del padre Saccheri el precursor de las grandes revoluciones representadas por las geometrías no euclidianas? ¿Y cómo dejar de lado a Gregorio Mendel, en la revolución genética? O también, ¿cómo dejar de lado al abate Lemaître, en el proceso de la 'revolución cosmológica' representada por la teoría de la bigbang?": R 87.

C) Hoy en día: "El escepticismo universal, el nihilismo, el relativismo, el subjetivismo psicologista", son como los sumideros por los que la racionalidad va "desviándose de sus propios cursos originarios": R 88. Y, contra este escepticismo universal, "la fe en el Dios omnisciente y humano de la Teología cristiana (es) como una medicina que ha salvado y aún puede seguir salvando a muchos grupos de personas de esa dolencia extrema de la razón", que no viene de "factores exógenos": R 89.

D) Además, dogmatismo y fundamentalismo crean despotismo pero: "La 'Ciudad de Dios' agustiniana, la Iglesia, pudo ir creando un amplio recinto de libertad frente al despotismo totalitario de la "Ciudad terrena": R 90. Luego, la historia se debate entre "El Imperialismo cristiano y el Imperialismo mahometano". Pero ya santo Tomás establece "las relaciones entre la Razón natural y la Revelación sobrenatural, reconociendo la imposibilidad de imponer esta Revelación por la fuerza". El cristianismo racionalizó la relación Iglesia-Estado con "dos sociedades perfectas" frente al "agustinismo político' y "la teocracia arriana o islámica”. Y, hoy, "proyectos fundamentalistas", como la Yihad islámica, "no se encuentran, ni de lejos, entre los cristianos de Occidente": R 90-91.

Por lo demás, la racionalidad del Dios trinitario cristiano no es solitaria ni autista sino relacional como "creador de un Mundo" y capaz de 
librar las masas populares "del pánico, del delirio, de la superstición o del horror", y mantiene una racionalidad cercana a la ciencia, la tecnología y la política, tal como "históricamente se han desarrollado en los pueblos llamados 'civilizados"”: R 91-2. Así: "No es difícil comprender, por tanto, que es precisamente el Dios de los cristianos quien ha salvado a la Razón humana a lo largo de la historia de Occidente" (cursiva mía). Y, debe seguir salvándola, en Oriente y Occidente, y en todo contacto "de cualquier otra estirpe, (que) ponga a la racionalidad históricamente conquistada ante el peligro de sus mayores extravíos": R 92.

\subsection{Wael Farouq: "En las raíces de la razón árabe”}

Benedicto XVI continúa el discurso sobre la desconfianza actual en la razón, descrita por Juan Pablo II $^{\circ}$ en Fides et Ratio, y su deriva a una "filosofía nihilista" que tiene "cierto atractivo entre nuestros contemporáneos"”: R 93. Así, el nihilismo es el origen de la mentalidad "según la cual no se debe asumir ningún compromiso definitivo, ya que todo es fugaz y provisional' (Fides et Ratio, n.46, 3 ${ }^{\circ}$ )": R 94. Un año antes del discurso de Ratisbona el Papa había publicado, Deus caritas est, $1, \mathrm{p} .3^{\circ}$, en la que afirmaba: "En un mundo en el cual a veces se relaciona el nombre de Dios con la venganza o incluso con la obligación del odio y la violencia, este (el mandamiento del amor) es un mensaje de gran actualidad y con un significado muy concreto". Así, fe y amor no son separables: "Solo el servicio al prójimo abre mis ojos a lo que Dios hace por mí y a lo mucho que me ama' (Deus caritas est, 18, 1)": R 94-95.

Occidente parece defender una razón que excluye lo divino. Pero: “Una razón que sea sorda a lo divino y relegue la religión al ámbito de las subculturas, es incapaz de entrar en el diálogo de las culturas"' (Discurso de Ratisbona, 16)": R 95. Esta crisis racionalista es una crisis de humanidad que lleva en Occidente a la violencia de su "espíritu nihilista" y "contra la vida humana encarnada en el espíritu del extremismo y del terrorismo en el mundo árabe": R 96. Por eso, se invita a hacer del Islam, que es una gran tradición religiosa rica en experiencias y convicciones, "una fuente del conocimiento". La razón debe abrirse a "la renovación y maduración" y buscar nuevos horizontes en el amor al otro como dicen los textos cristianos (1Jn 4,20; Mt 19,18) y del Islam: "No sois creyentes si no os amáis recíprocamente (del Profeta, traído por el Muslim)".Y: 
"Ninguno de vosotros es creyente si no desea para su hermano cuanto desea para sí mismo' (del Profeta, traído por al-Busari)": R 97.

Muchos textos árabes tratan la situación actual como dos grupos rivales: "unos rechazan la modernidad -incluso viviéndola- hasta llegar a la ruptura, mientras otros se identifican con ella hasta ver en la tradición y en el contexto histórico un obstáculo al progreso": R 99. Este desgarro se produce también en culturas como Japón: $\mathrm{R} 100$. "La dialéctica y la lucha entre los fundamentalistas guardianes de la identidad y los modernistas impulsores de la renovación es una dialéctica ilusoria y falsa": R 101. Unos creen resucitar al Profeta, los Califas, el historicismo o el marxismo. El fundamentalista vive del "aquí" pero no en el "ahora", y el modernista vive el "ahora" pero sin el "aquí". Ambos aman la tradición o a la modernidad pero se olvidan "de la realidad cotidiana" sin "reconocerlo": R 102. Entonces, hay que recuperar la tradición que sedimenta el hombre pero también "da forma a la identidad" con el hombre actual que le impulsa a "emplear todos sus recursos, movido por la esperanza de una vida mejor". "La identidad como 'materia y forma' garantiza la presencia de la tradición particular (árabe) y general (humana), dentro de la realidad que recibe forma del actual del Yo y del Otro": R 103. Una relación dialógica que las distingue y da independencia: R 105.

Por lo demás, hay juicios muy diversos sobre los árabes y su cultura, su lengua y su ciencia. Para Ibn Manzur: "La razón es el corazón y el corazón es la razón": R 112. El occidental edifica en el espacio y vive de él, el árabe lleva consigo la memoria y es nómada, así que: "No hay poesía para quien no tiene memoria (Mustafa Nasif)": R 115. La memoria es la vida y el árabe vive frente a "la muerte en el tiempo": R 116. El lenguaje, la razón (la memoria) y el tiempo fundamentan la "identidad" de la razón árabe desde sus "comienzos": "El árbol más importante en el desierto es 'el árbol genealógico'. Toda tribu es un árbol y el hombre en el desierto se define como rama en el árbol". Así se unen persona y comunidad, pues quien "no conoce a los parientes" no es "de la familia". "Por esta razón, el único rival serio del poeta en la sociedad preislámica es el genealogista". El genealogista, como "el poeta, es el guardián de la identidad de la sociedad y el garante de su continuidad": R 118-119. Así, el individuo, con su apego a la tribu manifiesta apego a sí mismo, pues identifica su persona y la tribu: "En el desierto el hombre es definido únicamente por su pertenencia a la tribu y solamente dentro de ella goza de una existencia per- 
sonal": R 120. Y, el mayor castigo es: ser expulsado de la tribu al quedar separado de la vida: $\mathrm{R} 121$.

Además, "An-Nu’man considera las 'virtudes' como tercer pilar básico de la identidad árabe": R 121. Y, se alaba la generosidad y sacrificar todo por el otro, lo que garantiza "fama y celebridad": "Las costumbres virtuosas son pues idóneas para constituir el tercer pilar de la identidad árabe, junto con el lenguaje y la lengua (o la tribu). Es el tercer componente de la razón árabe desde "sus inicios". "Sus rasgos de violencia, extremismo y santificación del pasado eran un modo para conservar la vida, no para anularla, para comprometerse con la realidad, no para abandonarla. Esta es la lección que debemos recabar hoy de esa experiencia humana": R 123-4.

\section{3.- André Glucksmann: "El espectro de Tifón”}

"El discurso de Ratisbona, al poner inmediatamente en el centro del diálogo entre las religiones, y del debate entre creyentes y no creyentes, el reto de la violencia, acierta a plantear la cuestión de las cuestiones, en la que se decide el destino del siglo XXI". Se trata de si la humanidad sabrá "dominar la violencia que hay en ella desde siempre" o morirá por sus pulsiones de muerte y sus infinitos "modos de matar". Glucksmann, el más importante de los Nuevos Filósofos, con su gran crítica a Los Maestros Pensadores, del s. XIX, propondrá aquí "los efectos propiamente filosóficos que se desprenden de un texto digno de otros muchos comentarios": R 125.

Según él, la razón humana da a todos "la posibilidad de alcanzar el 'agua profunda' del conocimiento (cf. Prov 20,5) (Fides et ratio 16,3): $\mathrm{R}$ 126. La violencia y su lucha "con la razón humana constituye el acto de nacimiento de la filosofía, originariamente definida por los pensadores griegos como "conocimiento de sí mismo"”. Al recordar a Tifón, ultimo titán contra los dioses, Sócrates le-se interroga: “¿(Soy por casualidad) una fiera más complicada y más orgullosa que Tifón, o un ser vivo más manso y más simple, partícipe por su naturaleza de una cierta condición divina y sin ínfulas de orgullo?" (Platón, Fedro, IV, 230ª)': R126. En el pensamiento occidental, la violencia proteiforme y bárbara es "la medida de la inhumanidad y de la humanidad del hombre". "Prueba infalible de la actual degradación del 'diálogo' entre las religiones es que quienes se ma- 
nifiestan lanza en ristre contra la cita retomada por Benedicto XVI confirman de este modo, sin darse cuenta, las críticas de Manuel II". "El discurso de Ratisbona, al recomendar la 'autocrítica', no atribuye solo a los musulmanes la facultad de deslizarse hacia el fanatismo de una fe que rechaza la ayuda de la razón": R 127. "Como su predecesor en la encíclica Fides et ratio, él (Benedicto XVI) subraya la exigencia de firme de lucidez a propósito del necesario 'acercamiento entre la fe bíblica y el filosofar griego': Ratisbona, 5)": R 127-8.

Así es como: "la frágil filosofía puede contribuir a frenar nuestras violentas arrogancias" porque desde el sentido común, la técnica y en los grandes temas de "la justicia, la virtud, la bondad" lo expertos critican y son duros como el hierro y "los cuchillos se afilan, al menos hasta que el filosofar griego reconduce a todos, sabios, sofistas o simples ciudadanos, a una ignorancia que todos se negaban admitir". "Si el discurso de Ratisbona insiste fuertemente en los peligros de una fe separada de la razón es porque esta última, aun presentándose de modo negativo representa una válvula de seguridad necesaria": R 128. "La civilización occidental no ha podido trasgredir nunca la regla socrática del libre examen, de todo por parte de todos, sin recibir graves daños. A pesar de esto, Sócrates fue condenado a muerte".

"Una fe que ignore o evite la modesta razón filosófica corre el riesgo de encontrarse en manos de una violencia ciega. La alternativa razónviolencia no enfrenta a unas religiones con otras, sino que sitúa a cada una frente a sí misma". "El Islam sufre una especia de kidnapping, de OPA; sus convicciones más sinceras son desviadas y confiscadas por un culto a la muerte terrorífico. En el s. XX el cristianismo europeo conoció un fenómeno semejante": R 129. Así ocurrió en la Ia . Guerra mundial y luego con el nazismo: R 130. Por lo demás: "En el pasado dos grandes renuncias han sido la desgracia de Europa: matar en nombre de Dios y cerrar los ojos. Semejante nihilismo homicida y suicida arrecia de nuevo en la actualidad planetaria. Hoy como ayer, resisten los justos, los héroes, los santos, a menudo simples ciudadanos": R 130. La idea de Ratisbona de una fe amiga de la razón "toca el punto más profundo del texto bíblico y de las meditaciones insondables de las tres religiones del libro": Quien mata en nombre de Dios “confunde a Dios con Tifón y se permite todo. Si no cree, mata en sí mismo la razón y se erige en supremo Tifón que no se prohíbe nada". "La literatura del siglo XIX, en su mayor parte rusa, ha explorado 
anticipadamente el callejón sin salida de una eliminación definitiva de las prohibiciones hacia la que se precipitarán, con la cabeza baja, un gran número de poseídos de los siglos XX y XXI": R 131.

Necesitamos a Atenas con Jerusalén, "la controversia típica del siglo XX entre cientificismo y fideísmo está esencialmente superada". "Como recordaba Fides et ratio, los textos sapienciales de la Biblia y la traducción de los Setenta dan testimonio de la perspectiva única del encuentro entre Jerusalén y Atenas": R 132. "Saber interrogativo, fuerza disuasiva más bien que persuasiva, el 'demonio' de Sócrates, que se limita a retener, simboliza la solidaridad de los guardianes laicos y religiosos sobre el borde del abismo". "Solidarios contra lo peor, unos simples ciudadanos inventaron un heroísmo imprevisto y superaron las divisiones seculares que los separaban política, ideológica, incluso religiosamente": R 133-4.

"El discurso de Ratisbona se basa implícitamente en la fuerza que ha levantado el telón de acero y ha abatido el muro de Berlín". Europa nunca se unió en torno a un bien sino en el rechazo del mal que es: "la violencia brutal (la 'guerra'), la miseria aniquilante (el hambre) y el desorden corporal físico absoluto (¿la peste?)”: R 134-5. “Una vez más solamente una visión lúcida (apofántica) de las amenazas que acechan a la colectividad permite reunir políticas sinceras y hombres de fe": R 135. "La fe cree, la razón sabe. La fe cree en el Bien. La razón apofántica conoce el Mal. Ambas son aquí complementarias, quizá también -como diría el escéptico- en las bodas del ciego con el lisiado. En esta misma precariedad, nuestros dos remedios son capaces de reunirnos contra lo peor, sino por lo mejor": R 135. "El nihilismo, aun antes de estar en contraposición con las exigencias y los contenidos de la palabra de Dios, niega la humanidad del hombre y su misma identidad" (Fides et Ratio, no 90)": R 136.

La razón y los credos parecen haber dimitido ante la violencia activa. Así: “Al final la razón no peca ya por arrogancia sino por renuncia suicida; propaga entre los posmodernos el odio por el pensamiento definido desde el comienzo como 'misología' por Sócrates (Fedón, 39, 89d-c), una vez más citado en Ratisbona": R 136. "Semejante eutanasia contemporánea de la razón no beneficia absolutamente a la fe": R 137. Así, las religiones y los pensadores se autoproclamaron "centinelas de la nada" o "pastores del ser". Pero: "Desde la colaboración de Platón con Dionisio, el tirano de Siracusa, hasta los peores compromisos de los zelotes de Lenin, Stalin o Hitler, el orgullo trascendental, que engulle de un solo bocado tanto la 
razón como la fe, nos hace precipitar de catástrofe en catástrofe. En el siglo XXI, al final posmoderno de los grandes relatos ideológico-históricos, el nihilismo prospera en la filosofía, "proclamando no solo la relatividad de los bienes y de los valores sino más radicalmente la relatividad del mal": "El suicidio de la razón socrática genera monstruos": R 138.

"Mata al prójimo como a ti mismo. El imperativo nihilista supera alegremente los confines geográficos y geopolíticos. Cubre ya todo el abanico de violencias posibles y hace proliferar la masacre de inocentes". Del terrorismo a la bomba atómica y Auschwitz se "ridiculiza la percepción del mal". Así que: Razón y fe deben enfrentar un desafío nuevo, porque: "el nihilismo trasforma la fuerza de hacer en capacidad de deshacer y la voluntad de poder en voluntad de dañar": R 138-9. "La universalidad 'negativa' del socratismo abre el tesoro universal de las virtudes cardinales en cuyo nombre, en todas las latitudes, la humanidad afronta la inhumanidad". "El nihilismo se esfuerza por hacer el mal invisible, indecible e impensable. Contra semejante devastación mental y mundial, la lección de Ratisbona vuelve a convocar a la 'la fe bíblica' y al 'filosofar griego' para que renueven sin concesiones una alianza que deseo sea definitiva y victoriosa": R 139 (París, enero 2007).

2.4. Jon Juaristi: “Teología".- Para este autor: "No es la idea de Dios lo que la modernidad no ha podido soportar, sino la idea del Dios razonable. La modernidad es el resultado de la des-helenización de Europa y de su consecuente abandono a los dioses oscuros e inexplicables": R 142. El texto del Papa ha sido sacado de contexto: "De su contexto discursivo, la admirable lección de Benedicto XVI, y de su contexto histórico, la Constantinopla asediada por los guerreros de Alá, tan tolerantes ellos": R 143.

\subsection{Sari Nusseibeh: "Violencia: racionalidad y razonabilidad".}

Para Ib Khaldun (†1406): “mientras las ciencias no-racionales, según él, están ligadas a los dogmas de la religión, las ciencias racionales no están sometidas a ningún dogma de este tipo": R 146. Por eso, los teólogos no pueden ponerse al nivel de los filósofos. Pero, para IbnTufayl o Avempace es "la pura experiencia mística, la que más acerca a la comprensión de Dios”: R 148. Y: “¡Para IbnHazm es el Amor, más que la Razón (como lo 
es para al-Farabi o para Averroes), el que hace girar el mundo!": R 149. Con todo, "las raíces helénicas" están "impresas en la tradición intelectual-islámica, tanto como en la cristiana": R 149. Y, en otras culturas hay también momentos de esplendor sin olvidar la crítica cristiana al helenismo ni la existencia de aspectos de esa cultura "también bárbaros y vergonzosos": R 150. Para el Papa, violencia y razón se excluyen, y "ser racionales (...) significaría ser no-violentos": R 152.

El Islam ha tenido que defenderse de la acusación de violencia tras los atentados de Torres Gemelas, y, hay que discutir la tesis del Papa de que "racionalidad y violencia son recíprocamente incompatibles": R 155. La primera cuestión es muy difícil de concretar dadas las diferentes posturas, textos y contextos. En cuanto a la segunda, el Papa defiende la unión de cristianismo y racionalidad anti-violenta. Eso mismo diría Averroes para el Islam. Pero, en cuanto al tema de la violencia como se ve en Maquiavelo o en Clausewitz: "no hay ninguna razón para sostener que el ser racional impida, desanime o retenga a los seres humanos de recurrir a la violencia": R 159. Pues, una cosa es la racionalidad y otra la racionabilidad serena, intelectual, psicológica y moral. Es la racionabilidad la que traza la línea de demarcación "entre los fieles píos o fanáticos, o entre los que trabajan por la paz y los asesinos": R 160.

Además, tenemos los textos Sagrados y su puesta en práctica. Y, todos debemos "ser respetuosos con una última dignidad de la humanidad, que todos compartimos, o ser respetuosos con la libertad, que todos tenemos, de elegir nuestro modo de llegar ser mejores seres humanos": R 162. En fin, como dice Pico de la Mirándola de Abdalá el Sarraceno que, al preguntarle sobre el gran espectáculo de este mundo, dijo que: "nada veía más espléndido que el hombre": R 162. Es de este respeto mutuo y convivencia y mutuo aprecio del que "podemos estar todos orgullosos, son estas las virtudes que debemos aprender a respetar y proteger todos": R 163.

\subsection{Robert Spaemann: "Benedicto XVI y la luz de la razón”.}

"Suscitar una discusión es lo mejor que le puede ocurrir a una lección magistral. Es lo que ha sucedido a la lección en Ratisbona de Benedicto XVI": R 166. "Frente al metodológico etsi Deus non daretur de la ciencia, el (Papa) postula un liberador etsi Deus daretur, que significa excluir 
desde el principio la “división de la razón'”: R 168. Es cierto que: “La verdad inevitablemente es intolerante. No hay tolerancia hacia el error, sino solo hacia el que yerra": R 170. El cristianismo se mezcló con el pensamiento griego para hacerse más "comprensible" y eso forma parte de "su identidad": "los filósofos platónicos de los que escribe Agustín que -a excepción de la encarnación del Logos- sobre las cosas eternas no pensaban de forma distinta de los "nuestros"”: R 171. Los pueblos germánicos añadieron "lo que era propio de ellos": R 170. Para Kant, pensamos en Dios pero nada sabemos de su existencia: "Podemos únicamente suponer su realidad y debemos afirmarla por una razón moral: para poder actuar moralmente hay que creer en una unidad última de virtud y felicidad. Y sólo Dios puede garantizar esa unidad": R 172. En un tiempo de impotencia de la razón, la Iglesia, del Vaticano I, hace artículo de fe no solo "creer en la existencia de Dios", sino también que "la razón humana" “es capaz de conocer al Creador del mundo": R 174.

Además, "(Jn 15,15), muestra que el seguimiento cristiano no es imitación ciega, sino obediencia inteligente": R 174. Es más, incluso Nietzsche: "Veía que si Dios no existe y el hombre no es un ser capaz de verdad, entonces no puede ni siquiera ser lo que cree ser: una persona": R 176. Y, tras Descartes, Kant y Nietzsche, "solo podemos poner juntas estas dos cosas: la fe en Dios y la afirmación de nosotros mismos como personas, es decir como seres capaces de verdad": R 178. O como dice Unamuno: "Sufro yo a tu costa, Dios no existente pues, si Tú existieras, existiría yo también de veras": R 178. "Razón significa auto-trascendencia, apertura hacia la realidad", -de ahí que: "Dios es amor (1Jn 4,16)" (y) “(Jn1,1): 'En el principio existía la palabra'- son inseparables y se explican recíprocamente": R 179.

Por todo lo cual: "Donde está vigente la violencia, la razón calla y la única forma de su duradera presencia puede ser sólo ese respeto a los enemigos que anticipa la reconciliación". Así, debemos pedir "la fuerza de amar a los enemigos. Semejante fuerza trasforma el status de la violencia que se opone a Dios y es el modo supremo con el que la luz puede iluminar las tinieblas, la luz de la razón y del amor, cuyo máximo testigo es en nuestro tiempo el papa Benedicto XVI": R 183. (Stuttgart, enero 2007). 
2.7. Joseph H. H. Weiler, "La tradición judeo-cristiana entre fe y libertad".

"Con humildad y temor", comenta este autor el discurso de Ratisbona aunque no es católico ni cristiano, pues, para Benedicto XVI la fe y la razón son el medio y el mensaje, y su consecuencia es la paz: $\mathrm{R} 185 ; 187$. "La paz pasa así a formar parte de la matriz inextricable, y hace la coerción y la violencia, en relación con el núcleo más profundo de la verdad de la fe, no simplemente inmorales per se, sino ontológicamente imposible, un verdadero oxímoron": R 187. El Dios cristiano es "no violencia" y "amor hasta el final" porque es "Aquel que murió por nosotros en la cruz: en Jesús, el Hijo de Dios encarnado, que aquí nos contempla con tanta insistencia. Su 'venganza' es la cruz". Y, así: "En dos mil años de densas, complejas y a veces dolorosas relaciones no ha existido nunca un diálogo judeo-cristiano mejor y más amplio que el iniciado por el gran Juan Pablo II y por su fiel Josué, Benedicto XVI": R 188-9.

Por eso: "puedo añadir muy poco al diluvio que ha caído sobre la cita de Manuel II el Paleólogo": R 189. Basta decir que el mundo sería mejor si tomase ejemplo de "la Iglesia católica en su esfuerzo continuo, sincero y difícil en la vía digna y honorable de arreglar cuentas con los episodios menos gloriosos de su pasado y de su enseñanza pasada". El mensaje cristiano se une a los más débiles y marginados, como el judaísmo y el Islam, y el Papa: "afirma que 'la cuestión social y el Evangelio son realmente inseparables": R 190.

Pero, además de la moral, "la santidad y la sacralidad denotan algo más". Y, es que como para el "católico la acción social y la Eucaristía son indispensables para la misión de la santidad. Para el creyente hebreo, los mandamientos que se refieren a las relaciones entre 'hombre y hombre' y los que se refieren a las relaciones entre 'el hombre y el Santo, sea por siempre Bendito" son indispensables en su "misión": R 191. Para el hebreo, la Ley es como la Eucaristía para el católico, es "la presencia real del Santo", "que no ha mandado simplemente 'amarás al tu prójimo como a ti mismo, sino 'amarás a tu prójimo como a ti mismo. Yo Yahveh". " Nuestra fe no la imponemos a nadie. Este tipo de proselitismo es contrario al cristianismo. La fe solo puede desarrollarse en la libertad' (s. 7) enseña el Papa a sus fieles": R 192-3.

La libertad religiosa nos lleva a ser seres "morales autónomos y soberanos" y negarla es "poner en peligro nuestra humanidad más ín- 
tima". No es preciso ser creyentes para ver que la "amenaza a la libertad religiosa constituye un ataque más profundo a la libertad individual". Así que: "Europa quiere hacerse valer en el mundo con el ejemplo, no con la fuerza" sino por la libertad y el amor que son las garantías de la verdadera humanidad: R 194-195. De este modo: "La tradición cristiana formulada por el Papa representa un 'acercamiento interior' entre 'la fe bíblica y el filosofar griego'. 'El cristianismo, no obstante ha tenido su origen y un importante desarrollo en Oriente', ha 'encontrado finalmente su impronta decisiva en Europa'". En efecto: "Europa ha tenido una influencia decisiva en el cristianismo, el cristianismo ha tenido una influencia decisiva en Europa, en lo que pertenece a Europa" que quiere liderar el humanismo de la libertad y el amor: R 198.

\subsection{Pablo Blanco Sarto y los "Ecos de Ratisbona"}

Este autor resalta que el Papa insiste pues en que: "Espero que el lector de mi texto comprenda inmediatamente que esta frase no expresa mi valoración personal con respecto al Corán, hacia el cual siento el respeto que se debe al libro sagrado de una gran religion" (n. 2. Benedikt XVI) ${ }^{2}$. De hecho, hay patologías de la razón y de la religión, y solo después de curadas esas patologías: "Occidente estará en perfectas condiciones para poder dialogar con las demás culturas" (n.14. Europa 80): CS 118. Pues, la religión sin razón carece de ética y derecho, y lleva al "terrorismo en nombre de Dios", al culto a la muerte e "ideologías totalitarias": CS 119. El Decálogo es un buen camino para "una auténtica batalla en favor del hombre y contra la deshumanización": solo la razón, abierta al Dios, "puede oponerse a instrumentalizar la idea de Dios", "ofrecer curación" a las patologáis de la religion, y, ser: "un baluarte del derecho" "para toda la humanidad": CS 120.

Por su parte, el Prefecto de la Fe, Müller, afirmó que: "En el discurso de Ratisbona (...), el papa Benedicto XVI ha realizado una síntesis entre fe y razón y entre amor y libertad. Cuatro conceptos que ha querido

${ }^{2}$ Benedicto XVI habla sobre: Cultura y sociedad. Rafael D. García y Pablo Blanco (Eds.).Comentarios de P. Blanco, D. Walsh y R. D. García. Palabra, Madrid 2013, 5. En adelante: CS. Presentación: Pablo Blanco Sarto -Facultad de Teología- Universidad de Navarra: (P). 
reivindicar en un mundo secularizado, como fuente y fundamento de una vida llena de sentido que se ha de manifestar en la sociedad actual": CS 123. W. Kasper llama a un diálogo pos-moderno entre fe y razón, pues el discurso de Ratisbona no solo "invita a las ciencias a abrirse a toda la realidad", sino que también invita "a la teología", a "un diálogo con la cultura secularizada de occidente”. Según Habermas: “"El lado religioso debe reconocer la autoridad de la razón 'natural' (...) 'Sin embargo la razón secular no debe postularse como juez de las verdades de fe"”: "Es más, "esa razón moderna se entenderá mejor a sí misma cuando aclare su propia postura respecto a la conciencia religiosa actual'": CS 126. De este modo, no solo se vive etsi Deus, religio et natura humana, non daretur sino también etsi Deus daretur de Pascal. Pues: “¿Qué hacer si no hay Dios, ni religión o ni siquiera naturaleza humana?" Una llamada, de la conciencia y la razón, "a una ética mundial, si bien Habermas se remitía al mero consenso social": CS 129.

T. Todorov, llama al diálogo entre los de la "pura religión" y la "pura razón”, e invoca a Averroes y santo Tomás, pues: “"El alma es razonable, de modo que hay que acercarse a ella mediante la razón, no con armas, sino con palabras' (n. 63)”. Y, resumía la postura del Papa:“"El Papa tiene razón cuando condena la violencia al servicio de las ideas, por más que sean las más justas del mundo' (...) 'Es cierto que Mahoma fue un guerrero violento, pero no lo fue siempre, y los partidarios de otras ideologías lo fueron también' concluye de un modo aparentemente conciliador": CS 135-6. Para Prades: "la razón (pos)moderna puede ser sanada y salvada por Dios", y critica "la 'razón absoluta' de la modernidad, que se ha desvinculado de Dios". Este es "el diagnóstico decisivo: la razón (pos) moderna se concibe de tal manera que no puede dar razón de sí misma" (n.71). La salvación de razón parcial sería abrirse a toda experiencia humana, que va de "lo sensible y sentimental" a la "experiencia de Dios, (n.72)": CS 137.

A. Ali Nayed, de la universidad de Cambridge, defiende los logros teológicos de los tratados sistemáticos del Islam y rechaza la violencia con la sura 2.256: "Ninguna violencia en cosas de fe". Piensa que el Corán de los musulmanes es "el camino hacia Dios por medio de la sabiduría, la formación integral y la argumentacion racional"”. "Nayed defendía con acierto la existencia de un islam racional y no violento. Sin embargo, pretendía mantener al mismo tiempo la dialéctica del cristianismo frente al 
islam, sin acoger la sugerencia de un puente mediador: el de razón": CS 140. Pone en duda la necesidad de lo griego y europeo, que Benedicto XVI considera "esenciales a la fe cristiana", y cree esta idea extraña a las 3 religiones.

Para Rémi Brague, no hay que callar a la razón ante la religión. Es más: "Concluía Brague, tras sostener que la Biblia exige la racionalidad, que 'hace falta una razón fuerte, incluso diría -sin tener miedo a las palabras- una metafísica', n.89": CS 141. Para Nusseibeh, el logos griego y el dabar bíblico se han impuesto en el mundo musulmán. Así, los clásicos fueron traducidos al árabe, antes que a las lenguas de Occidente (n.94): CS 142. Y: "Esta 'racionabilidad' (ampliada) de una fe religiosa es la que debería permitir el pluralismo, el diálogo democrático y también la 'mutua comprensión'. Son estos los valores -me parece-que el Papa proponía en su discurso, en un mundo que se percibe a sí mismo como amenazado por el fanatismo de la polarización y por el fantasma de la violencia', n.98": CS 143.

El foro católico-musulmán de Roma del 4-6.11.2008, asegura en su "Declaracion Final" que la dignidad humana de la persona nace de ser "creada por un Dios de amor y por amor, y ha sido dotada con los dones de la razón y el libre albedrío, y, capacitada para amar a Dios y a los demás". Con estos principios, la persona pide respeto a su dignidad y vocación, n.106. "Así, en este diálogo interreligioso, logos y eros, razón, naturaleza y libertad se encuentran unidos desde su mismo origen en Dios": CS 146.

\section{Fe, razón y religión en el mundo actual}

Aquí se trata de la fe y la razón en la construcción del hombre y la religión. Es el Discurso preparado para la visita, a la universidad de La Sapienza, y, del encuentro con: "El mundo de la cultura en el Collège des Bernardins". Ahí, Benedicto XVI, presenta "el reto de una razón nueva, de una 'razón ampliada' que fuera capaz de crear una nueva cultura y una nueva sociedad, 'una nueva Ilustración', había dicho ya como cardenal": P-CS 5. "Lejos de ser 'el último ilustrado' por su decidida defensa de la razón, Benedicto XVI se convertiría así en 'el primer posmoderno', por su propuesta de ampliar los límites de la razón moderna”: P-CS 6. 
No hay en el discurso de Ratisbona ningún ataque al Islam. Por eso, K. Lehmann, dijo que el tema tratado no era el Islam, sino la razón. Y, allí se habla de paz, razón y diálogo, y no de cruzadas, guerras santas o "choque de civilizaciones". Un texto muy universitario, que tanto revuelo levantó, pero que "venía sobre todo a recordar de modo paradójico una constante: la importancia de la razón -junto con el amor- en el cristianismo, la religión del logos y del ágape", como ha recordado, siempre, el "ahora Papa emérito": P-CS 6. De hecho, en diálogo con Habermas: "Razón y religión-concluyeron ambos-podían liberarse mutuamente de las 'respectivas patologías'. La razón podía impedir que la religión incurriera en el fanatismo y el fundamentalismo (y viceversa)'. Según Habermas, la razón secular debe aprender de la tradición judeo-cristiana, lo que pareció "un ataque al laicismo más laicista". Pero, él dice que "en un mundo post-secular no podemos actuar tan fácilmente como si Dios no existiera": P-CS 6-7.

"La posmodernidad nos ha hecho notar que los sueños de la razón moderna han producido también verdaderos monstruos, como dibujó Goya. Auschwitz, Hiroshima o Chernobyl serían tan solo algunos nombres de ciertos desafortunados experimentos. Y la religión puede y debe decir algo al respecto": P-CS 8. "Conviene crear una 'nueva Ilustración', una nueva cultura y una nueva sociedad, que requieren a su vez de una nueva razón, la 'razón ampliada", sin los errores de la razón moderna, cerrada al mundo del arte, la ética y los sentimientos, y "al inmenso panorama de las religiones y también de la fe cristiana”: P-CS 9.

\subsection{Discurso para el encuentro en la Universidad de La Sapienza}

Benedicto XVI suspendió su visita a la universidad de La Sapienza, de Roma, por el manifiesto suscrito por 77 profesores y la ocupación del Rectorado por 150 alumnos. Fue una cita, sacada de contexto, de un discurso de 1990: "En la época de Galileo -había dicho unos años antes-, la Iglesia permaneció mucho más fiel a la razón que el mismo Galileo. El proceso contra Galileo fue razonable y justo". Los denunciantes no explicaban, que esa frase era del filósofo de la ciencia P. Feyerabend. "Una atribución pues injusta": P-CS 10. Pues, la Iglesia rehabilitó a Galileo en 1992, con Ratzinger. 
A pesar del rechazo, el Papa envió el texto a La Sapienza invitando "a respetar siempre las opiniones de los demás y a buscar, con espíritu libre y responsable, la verdad y el bien”. Una pequeña referencia pedagógica "que a veces se permiten los viejos profesores": P-CS 11. Y, porque "también la Iglesia puede dar luces y sugerencias al mundo de la ciencia y a toda la sociedad actual", como madre de "una verdad que no le pertenece". "Cabe en este sentido una colaboración. Así, el testimonio de la Razón creadora, de la Razón-Amor que brinda el cristianismo puede ofrecer interesantes aportaciones y sugerencias a la ciencia y a la cultura seculares": P-CS 12. Pues, para los primeros intelectuales cristianos, preguntarse por el Dios más grande, su naturaleza y el sentido "del ser humano", era "parte esencial de su modo de ser religioso". "Así, en el ámbito de la fe cristiana, en el mundo cristiano, podía, más aún debía nacer la universidad": "Dios y la ciencia sobre Él cabían en la universidad", pues la universidad "nació en un contexto religioso": P-CS 14.

Después de la suspensión, muchos políticos e intelectuales lamentaban esta "oportunidad de tolerancia perdida", y 200.000 personas daban "su apoyo al Papa" en plaza San Pedro: P-CS 13. Recordaba Ratzinger que esta universidad, fundada por Bonifacio VIII, es ahora una Universidad estatal, "con un gran nivel científico y cultural, que la sitúa entre las universidades más prestigiosas del mundo" siempre comprometida "con la investigación y la formación de las nuevas generaciones". Y, añade: "Quiero recordar, en particular, el Encuentro mundial de Rectores con ocasión del Jubileo de las Universidades, en el que vuestra comunidad no solo se encargó de la acogida y la organización sino sobre todo de la profética y compleja propuesta de elaborar un nuevo humanismo para el tercer milenio": CS 45-46.

La Universidad de La Sapienza, "hoy es una universidad laica, con la autonomía que", desde su fundación, siempre fue el sentido de la universidad que está "vinculada exclusivamente a la autoridad de la verdad": CS 46. Y, también hoy, las religiones y la Iglesia repercuten en la sociedad. Y, su experiencia no se puede tirar sin más a la papelera de la "historia de las ideas", pues el Papa: "se ha convertido cada vez más también en una voz de la razón ética de la humanidad": CS 47.

De hecho, también los primeros cristianos supieron encontrar en el pensamiento griego una purificación de la religión mitológica, y fue para ellos un camino de encuentro con el Dios y el hombre auténtico que en- 
riqueció su fe, y: "La comprendieron como la disipación de la niebla de la religión mítica para dejar paso al descubrimiento de aquel Dios que es Razón creadora y al mismo tiempo Razón-Amor": CS 49. Así, en ese camino de búsqueda, "en el ámbito de la fe cristiana, en el mundo cristiano podía, más aún, debía nacer la universidad": CS 49. Pues en esa búsqueda de la verdad y la bondad: "La verdad nos hace buenos, y la bondad es verdadera, porque a ella se le concedió la visión del Logos, de la Razón creadora que, en la encarnación de Dios, se reveló al mismo tiempo como el Bien, como la bondad misma": CS 50.

Entonces, como la Medicina cura el cuerpo, el Derecho ordena la libertad humana en comunión con el prójimo. Así, hoy se impone "la cuestión de cómo se puede encontrar una normativa jurídica que constituya un ordenamiento de la libertad, de la dignidad humana y de los derechos del hombre". Una cuestión decisiva en "los procesos democráticos" y "de la que depende el futuro de la humanidad". "Yo considero significativo el hecho de que Habermas hable de la sensibilidad por la verdad (proceso de argumentación sensible a la verdad-dice-) como un elemento necesario en el proceso de la argumentación política, volviendo a insertar así el concepto de verdad en el debate filosófico y en el político": CS 5051.

En efecto, ya en el mundo medieval, con la Facultad de Derecho estaban las de Filosofía y de Teología, a las que se encomendaba la búsqueda del ser del hombre, y, "mantener despierta la sensibilidad por la verdad. Se podría decir incluso que este es el sentido permanente y verdadero de ambas Facultades: ser guardianes de la sensibilidad por la verdad, no permitir que el hombre se aparte de la búsqueda de la verdad": CS 52. Ahora bien, los Padres de la Iglesia consideraban el cristianismo como la verdadera Filosofía, pero santo Tomás propone la autonomía de la misma, sin subordinación ni división, como dos almas gemelas. Así, la Facultad de Filosofía que "había sido solo propedéutica con respecto a la teología, se convirtió entonces en una verdadera Facultad, en un interlocutor autónomo de la teología y de la fe reflejada en ella": CS 53.

Y, en esta unión, sin “confusión”, la Filosofía debe ser una búsqueda de la razón en libertad y responsabilidad, y ver sus límites, su grandeza y amplitud. "La teología debe seguir sacando de un tesoro de conocimiento que ella misma no ha inventado, que siempre la supera y que", al ser inagotable por la reflexión,"siempre suscita de nuevo el pen- 
samiento". Pero la Filosofía no debe separarse de la verdad ni "tampoco debe cerrarse ante lo que las religiones, y en particular la fe cristiana, han recibido y dado a la humanidad como indicación de camino": CS 53-4. Este mensaje cristiano tiene un sentido purificador que la filosofía debe aprovechar con su fuerza de verdad "contra la presión del poder y de los intereses": CS 54.

En este proceso, el hombre y el mundo se comprenden mejor a sí mismos y abren a la humanidad un saber y un poder inmenso que ha fructificado en "el conocimiento y el reconocimiento de los derechos y la dignidad del hombre", por lo que debemos estar agradecidos. Pero, el camino del hombre no se ha completado del todo y el peligro de caer en la inhumanidad no ha quedado descartado, como vemos por "la historia actual".

Hoy existe el peligro de que la Filosofía degenere, en puro positivismo y utilitarismo, y reducir la teología a la esfera privada y, que la razón pierda "la valentía por la verdad" y las aguas vivas de la vida. Así, Europa: si quiere construirse a sí misma solo sobre las propias argumentaciones "de lo que ahora convence", y, "preocupada por su laicidad, se aleja de las raíces de las que vive, entonces ya no se hace más razonable y más pura, sino se descompone y se fragmenta": CS 55-6. Con todo, el Papa no trata de imponer la fe ni su verdad contra la libertad de la universidad sino, con su ministerio pastoral, despertar la sensibilidad por la verdad e invitar a la razón "a buscar la verdad, a buscar el bien, a buscar a Dios; y, en este camino, estimularla a descubrir las útiles luces que han surgido a lo largo de la historia de la fe cristiana y a percibir así a Jesucristo como Luz que ilumina la historia y ayuda a encontrar el camino hacia el futuro": CS 56.

\section{2. "Encuentro con el mundo de la cultura en el Collège des Bernardins".}

"Gracias, Señor Cardenal, por sus amables palabras. Nos encontramos en un lugar histórico, edificado por los hijos de san Bernardo de Claraval" y que el cardenal "Jean-Marie Lustiger, quiso como centro de diálogo entre la sabiduría cristiana y las corrientes culturales, intelectuales y artísticas de la sociedad actual". Saludo a la Ministra de la Cultura y a los Srs. Giscard D'Estaing y Chirac, los Ministros que nos acompañan, los representantes de la UNESCO, al Alcalde de París y autoridades, y a "mis 
colegas del Instituto de Francia que tanto admiro. Doy gracias al Príncipe de Broglie por sus cordiales palabras". Agradezco a la delegación de la comunidad musalmana francesa, aquí presente, con mis mejores deseos para el Ramadán. Y un cordial saludo, al mundo de la cultura, que "representáis tan dignamente": CS 79.

Benedicto XVI habla del origen de la "teología occidental" y de "las raíces de la cultura europea". Y dice que "en la gran fractura cultural de "las migraciones de los pueblos y el nuevo orden de los Estados", en los monasterios "sobrevivían los tesoros de la vieja cultura", y, se iba formando "una nueva cultura". Su motivación y objetivo era: “quaerere Deum, buscar a Dios". El camino era la Palabra de las Escrituras. La búsqueda de Dios, requiere una cultura de la palabra o como dice J. Leclercq: en el monaquismo occidental, escatología y gramática están interiormente vinculadas una y otra (cfr: L'amour des lettres et le desir de Dieu, p.14). El deseo de Dios, le desir de Dieu, incluye el amor de la palabra y todas sus dimensiones. Pues la Palabra de Dios es su camino a nosotros y de nosotros a Él, y "hace falta aprender a penetrar en el secreto de la lengua, comprenderla en su estructura y en el modo de expresarse": CS 80-1.

"San Benito llama al monasterio una dominici servitii schola". El monasterio da eruditio y forma al hombre para servir a Dios. Esa, "formación" lleva a percibir "entre las palabras la Palabra": CS 81. Pero, la Palabra es un camino "individual de una inmersión mística" lleva a la comunión de los que viven la fe. "Y por eso hacer falta no solo reflexionar en la Palabra, sino leerla debidamente”. Y, “'si legere y lectio se usan sin adjetivo calificativo, indican comúnmente una actividad que, como cantar o escribir, afecta a todo el cuerpo y a toda el alma' dice a este respecto Jean Leclerq (ibíd., 35)": CS 82. La melodía lleva al hombre redimido a unirse a "los misterios que celebra", en Cristo, como dicen los capiteles de Cluny en sus símbolos de "cada uno de los tonos": CS 83 (cursiva, 2a, mía). Por eso, Bernardo de Claraval califica el "canto mal hecho" como una caída en la "la desemejanza, en la regio dissimilitudinis". Agustín usa esa expresión para describir su estado antes de la conversión (Confesiones VII, 10,16): el hombre, imagen de Dios, al abandonarlo se hunde en la desemejanza, lejos de Dios, y, así, se aleja "no solo de Dios, sino tambien de sí mismo, del verdadero ser del hombre": CS 83. 
"De esa exigencia intrínseca de hablar y cantar a Dios con las palabras dadas por Él mismo nació la gran música occidental”. No es una 'creatividad' privada, ni "un monumento a sí mismo", ni al propio yo, sino "reconocer atentamente con los 'oídos del corazón' las leyes", esenciales, "de la música puesta por el Creador en su mundo y en el hombre, y encontrar así la música digna de Dios, que al mismo tiempo es verdaderamente digna del hombre e indica de manera pura su dignidad" CS 84. Además, el sentido, "divino de la Palabra y de las palabras no es naturalmente obvio", pues: "El elemento histórico es la multiplicidad y la humanidad". De formula medieval algo desconcertante: "Littera gesta docet - quid credas allegoria...(cfr. Augustinus de Dacia, Rotulus pugillaris,1): "La letra muestra los hechos" y la fe "la alegoría, es decir, la interpretación cristológica y pneumática". Dicho sencillamente: "la Escritura precisa de la interpretación”, y "de la comunidad en la que se ha formado y en la que es vivida. En ella tiene su unidad y en ella se despliega el sentido que aúna todo". "El cristianismo capta en las palabras la Palabra, el Logos mismo, que despliega su misterio a través de tal multiplicidad y de la realidad de una historia humana". Así, la Biblia es un desafío nuevo para cada generación y "excluye" todo "fundamentalismo": CS 85.

Por eso, la unidad dinámica de los libros "forman un Libro, la Palabra de Dios y la acción de Dios en el mundo se revelan solamente en la palabra y en la historia humana". Esta grandeza de la Palabra bíblica, se ve en san Pablo que remite al interior del Espíritu y la libertad: "El Señor es el Espíritu, y donde hay el Espíritu del Señor hay libertad"(2 Cor 3,17). Ese Espíritu no es la propia idea ni la visión del intérprete: "El Espíritu es Cristo, y Cristo es el Señor que nos indica el camino": CS 86. Hay pues un límite a la subjetividad y la arbitrariedad. Sería fatal para la cultura europea tomar la libertad como la ausencia de vínculos que lleva "inevitablemente el fanatismo y la arbitrariedad. Falta de vínculos y arbitrariedad no son la libertad, sino su destrucción". En el divino servicio, s. Benito habla de la Palabra y el "ora" pero también del "labora". "En el mundo griego el trabajo físico se consideraba tarea de esclavos". "En cambio, en un capítulo de su Regla (san Benito) habla explícitamente del trabajo (cfr., cap. 48). Lo mismo hace Agustín, que dedicó al trabajo de los monjes todo un libro": CS 87. 
Es más: "Dios trabaja, ergázetai (Jn 5,17)". Y, el trabajo humano es "una expresión especial de la semejanza de Dios y el hombre", que participa "en la obra de Dios en la creación". En el monaquismo hay una "cultura de la palabra, una cultura del trabajo, sin la cual el desarrollo de Europa, su ethos y su formación del mundo son impensables". Si ese modelo Creador falta, el hombre se cree un creador deiforme y la formación del mundo se transforma en "destrucción": CS 88. Pero, con la vivencia de la Palabra, los primeros cristianos, como dice la Primera carta de Pedro: "Estad siempre prontos a dar razón (logos) de vuestra esperanza a todo el que os la pidiere $(3,15)$ ": CS 89 . No se trata de propaganda sino del poder de la Palabra. Así: "Para ellos la fe no pertenecía a las costumbres culturales, diversas según los pueblos, sino al ámbito de la verdad que igualmente tiene en cuenta a todos": CS 90.

Pablo no anuncia dioses desconocidos sino al que los hombres ignoran y conocen, a Aquel que buscan en su corazón, y, sin embargo, es el Incognoscible. El hombre profundo sabe que Él existe. Que el origen de todo no es la irracionalidad sino la Razón, no un ciego destino sino la libertad. Todos sabemos esto, según Pablo en la Carta a los Romanos $(1,21)$, pero si Él no se revela no llegamos a Él. La novedad del cristianismo no es su pensamiento sino un hecho: "Él se ha mostrado". Y, no es un hecho ciego sino que "es Logos, presencia de la Razón eterna en nuestra carne. Verbum caro factum est (Jn1,14)”. Así, “está el Logos, el Logos presente en medio de nosotros. El hecho es razonable. Ciertamente hay que contar siempre con la humildad de la razón para poder acogerlo; hay que contar con la humildad del hombre que responde a la humildad de Dios": CS 90-1.

Pero, hoy Dios se ha convertido en "el gran Desconocido" y hay inquietud por Él. Así: “Quaerere Deum, buscar a Dios y dejarse encontrar por Él”: es hoy muy necesario, pues una cultura positivista-subjetivista, que ve como "no científica la pregunta sobre Dios", es la muerte de la razón, "la renuncia a sus posibilidades más elevadas" y "la ruina del humanismo". La cultura europea como "búsqueda de Dios y disponibilidad para escucharle, sigue siendo aún hoy el fundamento de toda verdadera cultura": CS 91.

En fin, se pregunta Ratzinger: “¿Y Dios qué quiere exactamente de nosotros?": "Dios quiere que amemos, que seamos imagen y semejanza suya. Porque, como dice san Juan, Él es Amor y quiere que sus criaturas 
se asemejen a Él, que escogiendo libremente amar sean como Él, y le pertenezcan, para que así resplandezca su Amor"’. En efecto, como sentenció, en su viaje a Lourdes, el 14.9.2008, para celebrar los 150 años de las apariciones de María y llamar a la renovación del espíritu misionero, es necesario saber que solamente: "Volviéndose hacia Dios, el hombre llega a ser él mismo".

${ }^{3}$ RAtZInger, J., La sal de la tierra. Quién es y cómo piensa Benedicto XVI. Una conversación con Peter Seewald, eds. Palabra, Madrid 2005, 5ª 308 y final. 